\title{
PROSES KEPERAWATAN PADA PASIEN DEGENERATIF DI RUMAH SAKIT
}

\author{
Kiki Ramadhani \\ Email : Kikiirmdhn@gmail.com
}

\section{Latar Belakang}

Semua Manusia pasti akan mengalami fase yang sama dalam daur hidupnya, yaitu mulai dari lahir, bayi, anak-anak, remaja, lalu beranjak dewasa dan akhirnya tua. Seiring dengan berjalannya waktu setiap orang pasti mengalami pergantian atau regenerasi sel-sel dalam tubuhnya. Secara alamiah, sel tubuh manusia juga mengalami penurunan dalam fungsinya akibat proses penuaan. Proses kemunduran fungsi tubuh atau degeneratif merupakan proses alamiah tubuh manusia yang harus diperhatikan setiap orang (Hardisman, 2010). Masalah kesehatan yang dihadapi oleh negara Indonesia saat ini dipengaruhi oleh pola hidup, pola makan, faktor lingkungan kerja, olahraga, dan faktor stress. Perubahan gaya hidup terutama di kotakota besar menyebabkan terjadinya peningkatan prevalensi penyakit degeneratif. Perubahan gaya hidup pada masyarakat terutama dipicu karena peningkatan di berbagai sektor pendapatan ekonomi, kesibukan kerja yang tinggi dan promosi makanan trend asal barat, namun tidak diimbangi dengan pengetahuan dan kesadaran gizi yang seimbang. Akhirnya budaya makan berubah menjadi tinggi lemak jenuh dan gula, serta rendah serat dan rendah zat gizi mikro. Perubahan sosial ekonomi dan selera makan pada masyarakat akan mengakibatkan perubahan pada pola makan masyarakat yang cenderung menjauhkan konsep makanan yang seimbang, sehingga berdampak negatif terhadap kesehatan dan gizi. Pola makan tinggi lemak jenuh dan gula, serta rendah serat dan rendah zat gizi mikro akan menyebabkan masalah kegemukan, gizi lebih, serta meningkatkan radikal bebas yang akhirnya mengakibatkan perubahan pola penyakit dari infeksi penyakit kronis non infeksi atau munculnya penyakit degeneratif (Sandi R, Yuni Y, 2014). 


\section{Metode}

Metode yang digunakan dengan kajian pustaka terhadap beberapa referensi yang mendukung meliputi jurnal, teks book, tesis dan berbagai sumber lainnya. Pembahasan ini mempelajari tentang pasien degeneratif dan bagaimana proses keperawatan pada pasien degeneratif.

\section{Hasil}

Berdasarkan hasil penelitian dari beberapa literature yang diambil didapatkan metode beberapa penelitian mengenai penyakit degeneratif dan proses keperawatan pada pasien degeneratif. Penyakit degeneratif adalah penyakit kronik yang nantinya akan sangat mempengaruhi kualitas hidup seseorang. Salah satu contoh penyakit degenartif adalah diabetes mellitus dan hipertensi merupakan penyakit degeneratif. Penyakit degeneratif semakin berkembang karena menurunnya aktivitas fisik, gaya hidup dan pola makan. Penyakit degeneratif mempunyai tingkat mortilitas yang tinggi dan dapat mempengaruhi kuatitas hidup dan produktivitas seseorang. Salah satu resiko dalam terjadinya penyakit kardiovaskuler adalah hipekolesterolemia dan dislipidemia. Dua kondisi ini dapat disebabkan asupan makanan yang mengandung lemak dan kolesterol yang berlebihan. Serta, ketidakseimbangan asupan karbohidrat, lemak, dan serat juga menjadi resiko terjadinya obesitas dan diabetes melitus (Galuh RP, Syahrul A, 2018). Di Indonesia, penyakit degeneratif seperti hipertensi, diabetes mellitus, stroke, gagal ginjal kronik meningkat di tahun 2018 dari tahun 2013. Prevalensi diabetes mellitus tinggi pada orang yang berpendidikan tinggi dan apatur sipil negera (ASN). Kejadian penyakit degeneratif yang juga mulai menyerang usia lebih muda (>15 tahun) memerlukan peningkatan pengetahuan bagi setiap individu agar dapat mengenali lebih dini dan wasapada terhadap masalah kesehatan yang dialaminya. Untuk mencegah penyakit degeneratif semakin meningkat terutama diusia yang lebih muda sangat diperlukan pengetahuan dalam mengenali tanda dan gejala penyakit ini lebih awal dan memperbaiki pola dan gaya hidup. Dalam hal ini perlu dilakukan peningkatan pengetahuan masyarakat mulai dari usia lebih dari 15 tahun dan juga melakukan pemeriksaan kesehatan yaitu tekanan darah dan gula darah sebagai langkah awal untuk mendeteksi dini adanya penyakit degeneratif. 


\section{Pembahasan}

Keperawatan gerontik adalah suatu bentuk pelayanan profesional yang didasarkan pada ilmu dan kiat/teknik keperawatan yang bersifat konprehensif terdiri dari bio-psikososio-spritual dan kultural yang holistik, ditujukan pada klien lanjut usia, baik sehat maupun sakit pada tingkat individu, keluarga, kelompok dan masyarakat (UU RI No.38 tahun 2014). Pengertian lain dari keperawatan gerontik adalah praktek keperawatan yang berkaitan dengan penyakit pada proses menua (Kozier, 1987). Sedangkan menurut Lueckerotte (2000) keperawatan gerontik adalah ilmu yang mempelajari tentang perawatan pada lansia yang berfokus pada pengkajian kesehatan dan status fungsional, perencanaan, implementasi serta evaluasi. Berdasarkan pengertian tersebut dapat disimpulkan bahwa keperawatan gerontik adalah suatu bentuk praktek keperawatan profesional yang ditujukan pada lansia baik sehat maupun sakit yang bersifat komprehensif terdiri dari bio-psiko-sosial dan spiritual dengan pendekatan proses keperawatan terdiri dari pengkajian, diagnosis keperawatan, perencanaan, pelaksanaan dan evaluasi.

fokus keperawatan degeneratif antara lain

a. Peningkatan kesehatan (health promotion) Upaya yang dilakukan adalah memelihara kesehatan dan mengoptimalkan kondisi lansia dengan menjaga perilaku yang sehat. Contohnya adalah memberikan pendidikan kesehatan tentang gizi seimbang pada lansia, perilaku hidup bersih dan sehat serta manfaat olah raga.

b. Pencegahan penyakit (preventif) Upaya untuk mencegah terjadinya penyakit karena proses penuaan dengan melakukan pemeriksaan secara berkala untuk mendeteksi sedini mungkin terjadinya penyakit, contohnya adalah pemeriksaan tekanan darah, gula darah, kolesterol secara berkala, menjaga pola makan, contohnya makan 3 kali sehari dengan jarak 6 jam, jumlah porsi makanan tidak terlalu banyak mengandung karbohidrat (nasi, jagung, ubi) dan mengatur aktifitas dan istirahat, misalnya tidur selama 6-8 jam/24 jam. Konsep Lanjut Usia dan Proses Penuaan 
c. Mengoptimalkan fungsi mental. Upaya yang dilakukan dengan bimbingan rohani, diberikan ceramah agama, sholat berjamaah, senam GLO (Gerak Latih Otak) (GLO) dan melakukan terapi aktivitas kelompok, misalnya mendengarkan musik bersama lansia lain dan menebak judul lagunya.

d. Mengatasi gangguan kesehatan yang umum. Melakukan upaya kerjasama dengan tim medis untuk pengobatan pada penyakit yang diderita lansia, terutama lansia yang memiliki resiko tinggi terhadap penyakit, misalnya pada saat kegiatan Posyandu Lansia.

Proses keperawatan keperawatan yang dilakukan secara sistematis. Perawat menggunakan pengetahuan konprehensif untuk mengkaji masalah pasien, membuat penilaian yang bijaksana dan mendiagnosa, mengidentifikasi hasil akhir kesehatan pasien dan merencanakan, menerapkan dan mengevaluasi tindakan keperawatan yang tepat untuk mencapai tujuan merupakan pelaksanakan proses keperawatan (Dermawan, 2013). Asuhan profesional dituntut untuk dapat melaksanakan proses keperawatan dengan tepat dan benar. Pemahaman perawat terhadap proses keperawatan sangat penting, karena menjadi suatu hal yang utama dalam pelaksanaan asuhan keperawatan. Proses keperawatan akan membedakan asuhan keperawatan professional dengan asuhan keperawatan tradisional. Kemampuan perawat untuk menerapkan proses keperawatan tidak dapat ditawar-tawar lagi (Rohmah \& Walid, 2009).

Tahap-Tahap Proses Keperawatan

a. Pengkajian

Pengkajian merupakan pemikiran dasar yang bertujuan untuk mengumpulkan data, mengelompokkan data sesuai masalah dan mengklasifikasikan masalah berdasarkan kebutuhan pasien yang akan dipenuhi. Kebutuhan pasien terdiri dari biologis, psikologis, sosial dan spiritual (Effendi, 1995). Pada tahap pengkajian maka pasien maupun keluarga mengatakan tentang kondisi pasien jika keluarga mengatakan kurang mengetahui tentang penyakit yang dialaami pasien dan cara merawatnya maka dapat diasumsikan bahwa sikap keluarga dalam merawat pasien sangat dipengaruhi oleh pemahaman keluarga tersebut 
tentang tata cara perawatan hipertensi di rumah yang dapat diperoleh melalui pendidikan kesehatan (Mardhiah, 2013). Hal ini menunjukkan bahwa antara hasil studi kasus dan teori yang sudah ada tidak terdapat kesenjangan sesuai dengan pendapat Notoatmojo (2007) pendidikan kesehatan bertujuan untuk meningkatkan status kesehatan, mencegah timbulnya penyakit dan bertambahnya masalah kesehatan, mempertahankan derajat kesehatan yang sudah ada, memaksimalkan fungsi dan peran pasien selama sakit, serta membantu pasien dan keluarga untuk mengatasi masalah kesehatan.

b. Diagnosa

Diagnosa merupakan keputusan klinis mengenai masalah yang dialami pasien, keluarga, dan masyarakat (NANDA, 1990). Maka dari itu didapatkan diagnosa keperawatan yaitu ketidakefektifan pemeliharaan kesehatan keluarga berhubungan dengan ketidakmampuan keluarga merawat anggota keluarga yang sakit. ketidakefektifan pemeliharaan kesehatan keluarga adalah pola pengaturan dan pengintegrasi ke dalam kebiasaan terapeutik hidup sehari-hari untuk pengobatan penyakit dan sekuelnya yang tidak memuaskan untuk memenuhi tujuan kesehatan spesifik.. Penulis mengambil diagnosa ketidakefektifan pemeliharaan kesehatan mengacu pada batasan karakteristik yaitu adanya akselerasi gejala penyakit seorang anggota keluarga, kegagalan melakukan tindakan mengurangi faktor resiko, kesulitan dengan regimen yang ditetapkan,

ketidaktepatan aktivitas keluarga untuk memenuhi tujuan kesehatan, dan kurang perhatian pada penyakit (Herdman, 2015). Hal ini menunjukkan antara hasil studi kasus dan teori tidak ada kesenjangan bahwa batasan karakteristik yaitu adanya akselerasi gejala penyakit seorang anggota keluarga, kegagalan melakukan tindakan mengurangi faktor resiko, kesulitan dengan regimen yang ditetapkan, ketidaktepatan aktivitas keluarga untuk memenuhi tujuan kesehatan, dan kurang perhatian pada penyakit (Herdman, 2015).

c. Perencanaan 
Perencanaan merupakan susunan dalam setiap rencana tindakan yang akan dilakukan kepada klien, keluarga, dan masyarakat dalam mencapai tujuannya. Intervensi atau rencana keperawatan yang akan dilakukan yaitu yang pertama berikan pendidikan kesehatan mengenai proses penyakit yang dialami pasien degeneratif (pengertian, tanda dan gejala, penyebab, pencegahan, cara mengontrol dan pengobatan). Kedua yaitu berikan dukungan/motivasi pada keluarga membuat keputusan yang tepat dalam merawat klien dengan memberikan harapan pada klien dalam proses pengobatan . Ketiga yaitu libatkan keluarga dalam merawat klien. Kemudian yang selanjutnya yaitu memotivasi keluarga memeriksakan kesehatan secara rutin ke pelayanan kesehatan.

d. Implementasi

Pengaplikasian atau pelaksanaan dari setiap rencana yang telah disusun, perawat melaksanakan sesuai dengan identifikasi masalah klien. memberikan pendidikan kesehatan mengenai proses penyakitdegeneratif yang dialami pasien, memberikan dukungan pada keluarga membuat keputusan yang tepat dalam merawat klien, motivasi keluarga untuk memberikan harapan pada klien dalam proses pengobatan, melibatkan keluarga dalam merawat klien, memanajemen lingkungan yang aman, memotivasi keluarga untuk memeriksakan kesehatan secara teratur.

e. Evaluasi

Evaluasi merupakan tahap akhir dari proses keperawatan, pada tahap ini dilakukan penilaian keberhasilan asuhan keperawatan yang telah dilaksanakan. Setelah dilakukan impelementasi yaitu keluarga diberikan pendidikan kesehatan

Adapun tujuan keperawatan degeneratif antara lain :

a. Lanjut usia dapat melakukan kegiatan sehari-hari secara mandiri dan produktif.

b. Mempertahankan kesehatan serta kemampuan lansia seoptimal mungkin.

c. Membantu mempertahankan dan meningkatkan semangat hidup lansia (Life Support). 
d. Menolong dan merawat klien lanjut usia yang menderita penyakit (kronis atau akut).

e. Memelihara kemandirian lansia yang sakit seoptimal mungkin.

Peningkatan proporsi jumlah lansia perlu mendapatkan perhatian karena kelompok lansia merupakan kelompok dengan resiko tinggi yang mengalami masalah kesehatan khususnya perhatian dalam pelayanan kesehatan dari tenaga medis. Trend meningkatnya usia harapan hidup pada lanjut usia di Indonesia, membawa implikasi pada semakin banyaknya lanjut usia yang membutuhkan perawatan untuk mempertahankan status kesehatannya. Filosofi keperawatan pada lanjut usia adalah mempertahankan status kesehatan dengan adanya penurunan kemampuan pada lanjut usia baik fisik dan mental karena proses degenerative sampai menghantarkan pada proses kematian sejahtera. Untuk menciptakan hal demikian diperlukan keterampilan perawat khususnya gerontic nurse (perawat lansia) untuk memberikan pelayanan keperawatan terbaik didasarkan pada pengetahuan yang kuat (strong knowledge). Selain mempertahankan status kesehatan peran perawat lansia disini adalah mengatasi masalah kesehatan yang dialami lansia dimana proses penuaan akan mengakibatkan terjadinya beberapa perubahan fisiologis, anatomi, psikologis, dan sosiologis. Timbulnya penyakit yang menetap seperti Alzeimer/Demensia, gangguan sclerosis multiple, gangguan endokrin, dan lain-lain akan meningkat dengan bertambahnya usia, dengan kompleks penyakit lanjut usia maka diperlukan asuhan keperawatan yang khusus pula untuk mencapai kesembuhan yang paripurna.

Program pelaksanaa lansia yang dapat dilakukan antara lain :

1.Pengkajian( Program kerja awal yaitu pelaksaan program kerja pengkajian pada lansia )

2. Penyuluhan Kesehatan mengenai keluhkan lansia atau keluarga dari lansia

3. Pengobatan Gratis yang dilakukan meliputi pemeriksaan dan pemberian obat secara gratis

4. Senam Lansia

\section{Penutup}


Penyakit degeneratif adalah penyakit kronik yang nantinya akan sangat mempengaruhi kualitas hidup seseorang. Salah satu contoh penyakit degenartif adalah diabetes mellitus dan hipertensi merupakan penyakit degeneratif. Penyakit degeneratif semakin berkembang karena menurunnya aktivitas fisik, gaya hidup dan pola makan. Penyakit degeneratif mempunyai tingkat mortilitas yang tinggi dan dapat mempengaruhi kuatitas hidup dan produktivitas seseorang. Masalah kesehatan yang dihadapi oleh negara Indonesia saat ini dipengaruhi oleh pola hidup, pola makan, faktor lingkungan kerja, olahraga, dan faktor stress. Perubahan gaya hidup terutama di kotakota besar menyebabkan terjadinya peningkatan prevalensi penyakit degeneratif. Perubahan gaya hidup pada masyarakat terutama dipicu karena peningkatan di berbagai sektor pendapatan ekonomi, kesibukan kerja yang tinggi dan promosi makanan trend asal barat, namun tidak diimbangi dengan pengetahuan dan kesadaran gizi yang seimbang. Akhirnya budaya makan berubah menjadi tinggi lemak jenuh dan gula, serta rendah serat dan rendah zat gizi mikro. Proses keperawatan keperawatan yang dilakukan secara sistematis. Perawat menggunakan pengetahuan konprehensif untuk mengkaji masalah pasien, membuat penilaian yang bijaksana dan mendiagnosa, mengidentifikasi hasil akhir kesehatan pasien dan merencanakan, menerapkan dan mengevaluasi tindakan keperawatan yang tepat untuk mencapai tujuan merupakan pelaksanakan proses keperawatan (Dermawan, 2013).

\section{Daftar Pustaka}

Dinarti dan Mulyanti Yuli. (2017). Dokumentasi keperawatan. Bahan ajar keperawatan

Fitra A. lestari Nurinda . (2019). Asuhan keperawatan gerontik pada klien Ny.M dan Tn.K dengan depresi yang mengalami masalah keperawatan ketidakefektifan koping Di UPT pelayananan sosial Tresna Werdha Jember tahun 2019 (laporan tugas akhir) . Jember . Universitas Jember

Fridalni Nova,Guslinda, Aida Minropa Aida dkk. (2019).Pengenalan dini penyakit Degeneratif. Jurnal Abdimas Saintika.1(1) : 129-135

Hidayat, A. A. (2008). Pengantar Konsep Dasar Keperawatan. Jakarta: Salemba Medika. 
Iqbal B. Mohammad, Bidjuni Hendro, Bawotong Jeavery. (2017). Pengaruh Manajemen model Asuhan Keperawatan profesional Tim Terhadap Kualitas Pelayanan Keperawatan Di Bangsal Pria RSUD Datoe Binangkang Kabupaten Bolaang Mongondow. e-Jurnal Keperawatan (e-Kp) . 5(2): 1-6

Nanang R. Paramata. (2015). Pemberdayaan Proses keperawatan dalam penanggulangan penyakit degeneratif pada lansia (laporan akhir). Gorontalo . Universitas negeri Gorontalo

Nur K. Siti . (2016). Keperawatan gerontik. Modul bahan ajar cetak Keperawatan

Setiyorini Erni dan Arti W.Ning . (2018).Asuhan Keperawatan Lanjut Usia dengan Penyakit Degeneratif. Malang : media Nusa creative

Simamora, R. H. (2019). Development of Guidelines for Applying appropriate Patient Identification to Achieve Patient Safety Goal INC2019 12th International Nursing Conference. 2019.10455 - 455 (1 pages) UCI(KEPA) : 1410-ECN-0101-2019-512001224337

Simamora. R. H. (2008) The correlation of ward chief's giving direction and command and the performance of on-duty nurses at Jember dr. Subandi general hospital inpatient wards. jurnal Administrasi dan Kebijakan Kesehatan, (https://fkm.unair.ac.id/jurnal-administr)

Umar Rahmawati , V.Rottie Julia, Lolong Jill. (2017). Hubungan stress dengan citra tubuh pada penderita diabetes melitus tipe II di rumah sakit pancaran kasih GMIM Manado 2016. e-Journal Keperawatan (e-Kp). 5 (1)

Yustiana W. Ester . (2017). Asuhan keperawatan keluarga pada Tn.K dan Tn.W tahap perkembangan lansia dengan hipertensi dengan ketidakefektifan pemeliharaan kesehatan di dusun Jetak desa Wonorejo kecamatan Gondangrejo Kabupaten Karanganyar ( karya tulis ilmiah ). Surakarta . Sekolah tinggi ilmu kesehatan Kusuma Husada. 
